\title{
Various ester derivatives from esterification reaction of secondary metabolite compounds: a review
}

\begin{abstract}
Secondary metabolite compounds have a very diverse structure that is widely used as a source of new drug discovery because they have a variety of bioactivity. But in its development, there are several problems related to these compounds including low bioavailability, low solubility and instability in the metabolic process. Modification of the structure of secondary metabolites is used to answer all these problems. One of the processed was by synthesising the ester derivative compounds through the chemical and enzymatic esterification reaction. Esters derivatives of secondary metabolite compounds can increase the diversity of structures, allow for increased biological activity and even new biological activity of these compounds. This review will discuss various processes of modification of the structure of secondary metabolite compounds through chemical and enzymatic esterification reactions that have been reported from 1994-2019.
\end{abstract}

Keywords: synthesis, esterification reaction, secondary metabolite compounds, ester derivatives, enzymatic
Volume 5 Issue 3 - 2020

\author{
Mila Rosyda, Nanik Siti Aminah, Alfinda Novi \\ Kristanti \\ Department of Chemistry, Faculty of Science and Technology, \\ Universitas Airlangga, Komplek Kampus C UNAIR, JI. Mulyorejo, \\ Surabaya, 60115 Indonesia
}

\begin{abstract}
Correspondence: Nanik Siti Aminah, Department of Chemistry, Faculty of Science and Technology, Universitas Airlangga, Komplek Kampus C UNAIR, JI. Mulyorejo, Surabaya, 60115 Indonesia, Email nanik-s-a@fst.unair.ac.id
\end{abstract}

Received: June 09, 2020 | Published: June 22, 2020

\section{Introduction}

Natural product compounds were obtained from various organisms. Natural product compound consists of primary and secondary metabolites. Primary metabolites are compounds produced by living things and are essential in the process of cell metabolism for cell survival. Primary metabolites are consisting of carbohydrates, fats, proteins and nucleic acids. Secondary metabolites are compounds that are only found in certain organisms or groups of organisms and are found in nature in limited quantities. Secondary metabolite compounds consist of terpenoids, steroids, phenyl propanoids, flavonoids, stylbenoids and alkaloids. ${ }^{1}$ Natural product compounds have extraordinary potential to be developed into high value products both as pharmaceutical products, nutritional products, functional foods, and cosmetics. ${ }^{2}$

Secondary metabolites have a very diverse structure that is widely used as a source of new drug discovery because it has a variety of bioactivity. ${ }^{3}$ Even though there are many secondary metabolite compounds that have the potential to become new drug candidates, there are still some problems related to these compounds. These problems include bioavailability and low solubility and instability in the metabolic process. ${ }^{4-6}$ Therefore, many structural modifications are made to natural product compounds to enrich new structures, allowing an increase their biological activity and even new biological activity of these compounds, so that the discovery of new drugs is growing. One of the processed of structural modification is by synthesising its ester through the esterification reaction.

Esterification reaction is a reaction between carboxylic acid compounds and their derivatives with alcohol to form ester compounds. Esterification reaction of secondary metabolite compounds can be done through esterification reactions by chemical or enzymatic reactions. Esterification reaction using a chemical catalyst is used because the process is relatively easy, but the selectivity is low and requires expensive costs. In recent years, the reaction approach using enzyme catalysts is in great demand. The enzymatic approach is preferred because of its high catalytic efficiency, enables easier and efficient separation of compounds, mild reaction conditions, require lower costs and environmentally friendly process. ${ }^{7-10}$ Based on several studies have reported that the lipase enzyme has been widely used as a catalyst for ester synthesis. Lipase (EC 3.1.1.3) functions to catalyze various reactions such as, esterification, hydrolysis and transesterification. ${ }^{11,12}$ Some lipase enzymes used for catalysts in esterification reagents include Lipozyme TLIM, Lipozyme 435, Novozym 435, Porcine pancreatic lipase. ${ }^{13-19}$

So far there has not been review that discusses the various processes of the esterification reaction of secondary metabolite compounds. Therefore, this article will discuss the process of modification of the structure of secondary metabolite compounds through chemical and enzymatic esterification reactions that have been reported from 19942019. This review aims to provide various references regarding the synthesis of esters derived from secondary metabolites.

\section{Ester derivatives from various secondary metabolites}

\section{Ester derivatives of cinnamic acid}

Cinnamic acid is one of the phenolic compounds of the phenyl propanoid group. Several researchers have reported the synthesis of esters from cinnamic acid (1) through enzymatic esterification reactions in solvent free or organic solvent systems. Some of these esters include ethyl cinnamate (2), butyl cinnamate (3), benzyl cinnamate (4) and cinnamic acid L-ascorbate (5). 5,16,27,28 Ethyl cinnamate was synthesized from esterification reaction with Lipozyme TLIM catalyst. The reaction mixture containing cinnamic acid and ethanol in isooctane was incubated in incubator shaker at $40^{\circ} \mathrm{C}$ at $170 \mathrm{rpm}$ and produced high yield of $86 \% .{ }^{27}$ Several researches were synthesized ethyl cinnamate (2), but the yield is very low. Synthesis of ethyl cinnamate (2) was also catalyzed by Novozym 435 enzyme through esterification reaction of cinnamic acid with ethanol. Yield of ethyl cinnamate is very low (2\%) and requires a long-time reaction (7 
days). ${ }^{13}$ Other researchers have synthesized ethyl cinnamate (2) using Porcine lipase as a biocatalyst. ${ }^{14}$ Ethyl cinnamate (2) was synthesized by enzymatic reactions using Novozym 435 lipase and the yield of $35.2 \%{ }^{16}$

Butyl cinnamate (3) was synthesized from esterification reaction of cinnamic acid (1) with the Novozym 435 lipase catalyst. The reaction mixture containing cinnamic acid (1), butanol in hexane and incubated in a temperature-controlled incubator shaker at $30^{\circ} \mathrm{C}$ at $250 \mathrm{rpm} .{ }^{16}$ Benzyl cinnamate (4) was synthesized from esterification reaction of cinnamic acid (1) with benzyl alcohol and catalyzed by Lipozyme TLIM in several organic solvents such as acetone, trichloromethane, methylbenzene, and isooctane. The reaction mixture was incubated in an incubator shaker at $150 \mathrm{rpm}$ at $40^{\circ} \mathrm{C}$. Based on this reaction, isooctane media produced the highest yield. ${ }^{28} \mathrm{~L}$-ascorbyl cinnamate (5) was synthesized through esterification reaction which is catalyzed by Lipozyme TLIM and Novozym 435 enzyme in various solvents including methanol, ethanol, acetonitrile, and acetone. Acetone and acetonitrile were reported as the most suitable media. Lipase catalyzed using Lipozyme TLIM dan Novozym 435 gave a maximum yield of $99 \% .{ }^{15}$ Addition of $\mathrm{Ph}-\mathrm{TiO} 2$ to the enzymatic esterification reaction for formation of cinnamyl ester was reported to increase catalytic efficiency in the reaction (Figure 1) (Figure 2) (Table 1). ${ }^{29}$

Table I Reagents, conditions and yield in esterification reactions of cinnamic acid

\begin{tabular}{lllll}
\hline Compounds & R reagent & Enzyme & Yield (\%) & Reference \\
\hline$(2)$ & EtOH & Lipozyme TLIM & 86 & Wang et al., ${ }^{18}$ \\
$(3)$ & Buthanol & Novozym 435 & 46 & Jakovetic et al.,'16 \\
$(4)$ & Benzyl alcohol & Lipozyme TLIM & 79.88 & Wang et al.., ${ }^{27}$ \\
$(5)$ & L-ascorbic acid & Lipozyme TLIM Novozym 435 & 99 & Zhang, ${ }^{15}$ \\
\hline
\end{tabular}<smiles>CC(=O)C=Cc1ccccc1</smiles>

(1)<smiles>COC(=O)/C=C/c1ccccc1</smiles>

(2) $R=$ Ethyl

(3) $R=$ Buthyl

(4) $R=$ Benzyl

(5) $R=$ L-ascorbyl

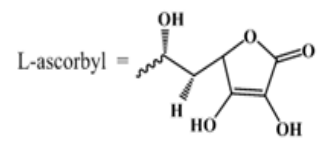

Figure I Structure of cinnamic acid compounds and cinnamic acid derivative esters.

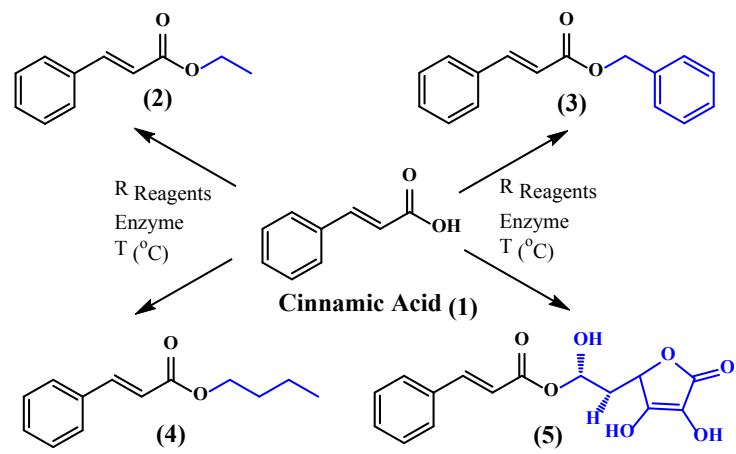

Figure 2 Esterification reaction of cinamic acid with enzyme catalyst.

\section{Ester derivatives of eugenol}

Eugenol (6) is one of the phenolic compounds from phenylpropanoid group. Eugenol (6) was isolated from various plants including Eugenia caryophyllata, Pimenta racemosa, Cinnamomum verum, Caryophyllus aromaticus, and Syzygium aromaticum..$^{17,22}$ Several ester compounds from eugenol were synthesized through chemical and enzymatic esterification. Eugenol derivative esters compounds that were reported their synthesis process, include eugenyl acetate or 4-allyl-2-methoxyphenyl acetate (7), eugenyl caprylate (8), and eugenyl benzoate (9) (Figure 3).<smiles>C=CCc1ccc(O)c(OC)c1</smiles>

(6)<smiles>[R]C(=O)Oc1ccc(CC=C)cc1OC</smiles>

(7) $\mathrm{K}=$ Methyl

(8) $\mathrm{R}=$ caprylyl $\left(\mathrm{C}_{7} \mathrm{H}_{15}\right)$

(9) $\mathrm{R}=$ Phenil
Figure 3 Structure of eugenol compound and eugenol derivative esters.

Eugenyl acetate [4-allyl-2-methoxyphenyl acetate] (7) can be synthesized through reaction of eugenol (6) with acetic anhydride and pyridine to gave yield of $63.20 \%{ }^{22}$ Eugenyl acetate (7) was also synthesized from reaction of eugenol (6) with acetic anhydride and $\mathrm{NaOAc}$ to produce eugenyl acetat (7) of $63.65 \% .{ }^{30}$ In addition, the synthesis of eugenyl acetate (7) was carried out through an esterification reaction between acetic anhydride and $\mathrm{NaOH}$ and produced $86.87 \%$ eugenyl acetate product. ${ }^{23}$

Several researchers have also reported the synthesis of eugenyl acetate (7) through an enzymatic esterification reaction using Lipozyme TLIM lipase and Novozym 435 as a catalyst and acetic anhydride as an acyl donor. ${ }^{17,19}$ Eugenyl acetate is also produced by esterification of eugenol (6) and acetic anhydride in $\mathrm{SC}_{-} \mathrm{CO}_{2}$ using two lipase enzymes as catalysts namely Lipozyme 435 and Novozym 435. Eugenyl acetate was also produced by esterification of eugenol (6) and acetic anhydride in $\mathrm{SC}-\mathrm{CO}_{2}$ using two lipase enzymes as catalysts namely Lipozyme 435 and Novozym 435 . The Novozym 435 gave higher yield than Lipozyme 435. ${ }^{31}$

Eugenyl caprylate (8) was produced through the esterification of eugenol (6) with caprylic acid using Lipozyme TLIM as a catalyst. Eugenol (6), caprylic acid and Lipozyme TLIM enzyme were reacted into the n-hexane solvent at $65^{\circ} \mathrm{C}$ and stirred at $250 \mathrm{rpm}$ for 259 minutes. This condition was optimum to give good yield of $72 \% .^{33}$ Eugenyl benzoate (9) was synthesized by an enzymatic reaction between benzoic acid and eugenol (6) using S. aureus lipase [24] and Rhizomucormiehei lipase as a biocatalyst. ${ }^{34,35}$ The reaction mixture was incubated and shaken with heating. The yield of eugenol benzoate products through enzymatic esterification reaction using $\mathrm{S}$. aureus lipase and Rhizomucormiehi were $56.13 \%$ and $65 \%$ (Figure 4) (Table 2). 
Table 2 Reagents, conditions and yield in esterification reactions of cinnamic acid

\begin{tabular}{|c|c|c|c|c|c|}
\hline Compounds & $R$ reagent & Catalyst/Enzyme & $\mathbf{T}\left({ }^{\circ} \mathrm{C}\right)$ & Yield (\%) & Reference \\
\hline \multirow{5}{*}{ (7) } & \multirow{5}{*}{ Acetic anhydride } & Pyridine & $\mathrm{Rt}$ & 63.2 & Carasso et al.,22 \\
\hline & & $\mathrm{NaOAc}$ & 80 & 63.65 & Manoppo, ${ }^{30}$ \\
\hline & & $\mathrm{NaOH}$ & 7080 & 86.87 & Riswanto, ${ }^{23}$ \\
\hline & & Lipozyme TLIM & 55 & 93 & Machado et al., ${ }^{19}$ \\
\hline & & Novozym 435 & 60 & 99.87 & Vanin et al., ${ }^{17}$ \\
\hline (8) & Caprylic acid & Lipozyme TLIM & 65 & 72 & Chaibakhsh et al., ${ }^{33}$ \\
\hline \multirow[t]{2}{*}{ (9) } & Benzoic Acid & S. aureus lipase & 41 & 75 & Horchani et al., ${ }^{24}$ \\
\hline & & Rhizomucormiehi & $50-65$ & $56-66$ & Manan et al., $, 34,35$ \\
\hline
\end{tabular}

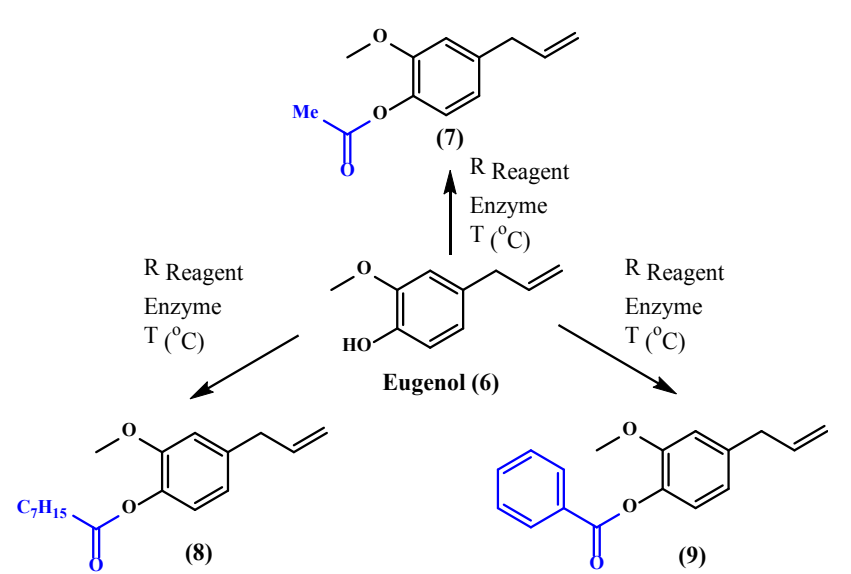

Figure 4 Esterification reaction of eugenol.

\section{Ester derivatives of quercetin}

Quercetin (10) is one of the phenolic compounds from flavonoid group. Several ester compounds from Quercetin (10) were synthesized through chemical and enzymatic esterification reaction. 3,3', 4',7-tetraacetate quercetin (11) have been synthesized through the esterification reaction between quercetin (10) with acetic anhydride and using pyridine as a catalyst at room temperature for three hours. This process produced $75 \%$ of esters. ${ }^{36} 3,3$, $, 5,7$-tetraacetate quercetin (12) was produced by the esterification reaction of acetic anhydride and pyridine at room temperature for 24 hours and gave yield of $70 \%{ }^{38} 3,3^{\prime}, 4^{\prime}, 7$-tetraethylcarbamate quercetin (13) was synthesized from the mixture of quercetin, ethylbromo acetate, $\mathrm{K}_{2} \mathrm{CO}_{3}, \mathrm{KI}$, and acetone at $55^{\circ} \mathrm{C}$ for 6 hours..$^{5}$

3,3',4',7-tetraisobutyrate quercetin (14), 3,3',4',7-tetrapivalate quercetin(15), and 3,3', 4',7-tetrabenzoate quercetin(16) were obtained

Table 3 Reagents, conditions and yield in esterification reactions of quercetin from the reaction of quercetin (10) and several acid anhydrides with pyridine as a catalyst at various conditions. 3,3', 4',7-tetraisobutyrate quercetin (14) was produced from the reaction of $1 \mathrm{~mol}$ of quercetin (10), $12.6 \mathrm{~mol}$ of Isobutyric anhydride and pyridine at $70^{\circ} \mathrm{C}$ for 2 hours and produced good yield of $96 \%$. 3,3', 4',7-tetrapivalate quercetin (15) was synthesized through the reaction between $1 \mathrm{~mol}$ of quercetin (10) with $24 \mathrm{~mol}$ of pivalate anhydride and pyridine at $65^{\circ} \mathrm{C}$ for 45 minutes and produced ester product (15) of $85 \%$. While 3,3', $4^{\prime}, 7$-tetrabenzoate quercetin (16) was synthesized from the reaction of $1 \mathrm{~mol}$ of quercetin (10) with $12.6 \mathrm{~mol}$ of benzoyl chloride and pyridine at $70^{\circ} \mathrm{C}$ for 2 hours and produced $72 \%$ ester product. ${ }^{36}$

Several researches have also reported the process of the synthesis of quercetin pentaasil compounds. 3,3',4',5,7-pentaacetate quercetin (17) was synthesized from the reaction between quercetin (10) with acetic anhydride and pyridine as catalysts in various conditions, including heated at temperature of $55^{\circ} \mathrm{C}$ for 6 hours, ${ }^{4}$ at $65^{\circ} \mathrm{C}$ for 5 hours with yield of $79 \%,{ }^{36}$ at room temperature for 24 hours $^{25}$ and at $80^{\circ} \mathrm{C}$ for 5 days. ${ }^{37} 3,5,7,3^{\prime}, 4^{\prime}$-pentaaisobirat quercetin (18), $3,5,7,3^{\prime}, 4^{\prime}$ '-pentapivalate quercetin (19), and 3,5,7,3',4'- quercetin pentabenzoate (20) were obtained by the esterification reaction between quercetin (10) with some acid anhydrides and pyridine as catalyst at various conditions. 3,5,7,3',4'-pentaisobutyric quercetin (18) was produced from the reaction between $3 \mathrm{~mol}$ of quercetin (10) with $30 \mathrm{~mol}$ of isobutyric anhydride and pyridine at $65^{\circ} \mathrm{C}$ for 2 hours and produced good yield of $97 \%$. 3,5,7,3',4'-pentapivalate quercetin (19) was produced through the reaction of $1 \mathrm{~mol}$ of quercetin (10) with $30 \mathrm{~mol}$ of pivaloyl chloride and pyridine at $65^{\circ} \mathrm{C}$ for 2 hours and produced of $87 \%$ ester. While 3,5,7,3',4'-pentabenzoate quercetin (20) was synthesized by the esterification reaction of 1 mol of quercetin (10) with $30 \mathrm{~mol}$ of benzoyl chloride and pyridine at room temperature for 3 hours and gave good yield of $98 \%$ (Figure 5) (Table 3). ${ }^{36}$

\begin{tabular}{llllll}
\hline Compounds & R reagent & Catalyst/Enzyme & $\mathbf{T}\left({ }^{\circ} \mathbf{C}\right)$ & Yield (\%) & Reference \\
\hline$(11)$ & Acetic anhydride & Pyridine & $\mathrm{Rt}$ & 75,00 & Mattarei et al., ${ }^{36}$ \\
$(12)$ & Acetic anhydride & Pyridine & $\mathrm{Rt}$ & 70,00 & Ortega et al., $^{38}$ \\
$(13)$ & Ethylbromo acetate & $\mathrm{K}_{2} \mathrm{CO}_{3}$ & 55 & 95,00 & Hu et al., ${ }^{5}$ \\
$(14)$ & Isobutyric anhydride & Pyridine & 70 & 96,00 & Mattarei et al.., \\
$(15)$ & Pivalic anhydride & Pyridine & 65 & 85,00 & Mattarei et al., ${ }^{36}$ \\
$(16)$ & Benzoyl chloride & Pyridine & 70 & 72,00 & Mattarei et al.,.36 \\
\hline
\end{tabular}




\begin{tabular}{|c|c|c|c|c|c|c|}
\hline Compounds & $R$ reagent & \multicolumn{2}{|c|}{ Catalyst/Enzyme } & $\mathbf{T}\left({ }^{\circ} \mathrm{C}\right)$ & Yield (\%) & Reference \\
\hline (17) & Acetic anhydride & \multicolumn{2}{|l|}{ Pyridine } & 65 & 79,00 & Mattarei et al.,., \\
\hline (I8) & Isobutyric anhydride & \multicolumn{2}{|l|}{ Pyridine } & 65 & 97,00 & Mattarei et al., ${ }^{36}$ \\
\hline (19) & Pivaloyl chloride & \multicolumn{2}{|l|}{ Pyridine } & 65 & 87,00 & Mattarei et al., ${ }^{36}$ \\
\hline (20) & Benzoyl chloride & \multicolumn{2}{|l|}{ Pyridine } & 65 & 98,00 & Mattarei et al., ${ }^{36}$ \\
\hline Compounds & $\mathbf{R}_{1}$ & $\mathbf{R}_{2}$ & \multicolumn{2}{|l|}{$\mathbf{R}_{\mathbf{3}}$} & $\mathbf{R}_{4}$ & $\mathbf{R}_{\mathbf{5}}$ \\
\hline (II) & $\mathrm{COCH}_{3}$ & $\mathrm{H}$ & \multicolumn{2}{|c|}{$\mathrm{COCH}_{3}$} & $\mathrm{COCH}_{3}$ & $\mathrm{COCH}_{3}$ \\
\hline (I2) & $\mathrm{COCH}_{3}$ & $\mathrm{COCH}_{3}$ & \multicolumn{2}{|c|}{$\mathrm{COCH}_{3}$} & $\mathrm{COCH}_{3}$ & $\mathrm{H}$ \\
\hline (13) & $\mathrm{COOC}_{2} \mathrm{H}_{5}$ & $\mathrm{H}$ & \multicolumn{2}{|c|}{$\mathrm{COOC}_{2} \mathrm{H}_{5}$} & $\mathrm{COOC}_{2} \mathrm{H}_{5}$ & $\mathrm{COOC}_{2} \mathrm{H}_{5}$ \\
\hline (14) & $\mathrm{COCH}\left(\mathrm{CH}_{3}\right)_{2}$ & $\mathrm{H}$ & \multicolumn{2}{|c|}{$\mathrm{COCH}\left(\mathrm{CH}_{3}\right)_{2}$} & $\mathrm{COCH}\left(\mathrm{CH}_{3}\right)_{2}$ & $\mathrm{COCH}\left(\mathrm{CH}_{3}\right)_{2}$ \\
\hline (15) & $\mathrm{COC}\left(\mathrm{CH}_{3}\right)_{3}$ & $\mathrm{H}$ & \multicolumn{2}{|c|}{$\mathrm{COC}\left(\mathrm{CH}_{3}\right)_{3}$} & $\mathrm{COC}\left(\mathrm{CH}_{3}\right)_{3}$ & $\mathrm{COC}\left(\mathrm{CH}_{3}\right)_{3}$ \\
\hline (16) & $\mathrm{COC}_{6} \mathrm{H}_{5}$ & $\mathrm{H}$ & \multicolumn{2}{|c|}{$\mathrm{COC}_{6} \mathrm{H}_{5}$} & $\mathrm{COC}_{6} \mathrm{H}_{5}$ & $\mathrm{COC}_{6} \mathrm{H}_{5}$ \\
\hline (17) & $\mathrm{COCH}_{3}$ & $\mathrm{COCH}_{3}$ & \multicolumn{2}{|c|}{$\mathrm{COCH}_{3}$} & $\mathrm{COCH}_{3}$ & $\mathrm{COCH}_{3}$ \\
\hline (18) & $\mathrm{COCH}\left(\mathrm{CH}_{3}\right)_{2}$ & $\mathrm{COCH}\left(\mathrm{CH}_{3}\right)_{2}$ & \multicolumn{2}{|c|}{$\mathrm{COCH}\left(\mathrm{CH}_{3}\right)_{2}$} & $\mathrm{COCH}\left(\mathrm{CH}_{3}\right)_{2}$ & $\mathrm{COCH}\left(\mathrm{CH}_{3}\right)_{2}$ \\
\hline (19) & $\mathrm{COC}\left(\mathrm{CH}_{3}\right)_{3}$ & $\mathrm{COC}\left(\mathrm{CH}_{3}\right)_{3}$ & \multicolumn{2}{|c|}{$\mathrm{COC}\left(\mathrm{CH}_{3}\right)_{3}$} & $\mathrm{COC}\left(\mathrm{CH}_{3}\right)_{3}$ & $\mathrm{COC}\left(\mathrm{CH}_{3}\right)_{3}$ \\
\hline (20) & $\mathrm{COC}_{6} \mathrm{H}_{5}$ & $\mathrm{COC}_{6} \mathrm{H}_{5}$ & \multicolumn{2}{|c|}{$\mathrm{COC}_{6} \mathrm{H}_{5}$} & $\mathrm{COC}_{6} \mathrm{H}_{5}$ & $\mathrm{COC}_{6} \mathrm{H}_{5}$ \\
\hline
\end{tabular}

Figure 5 Esterification reaction of quercetin.

\section{Ester derivatives of resveratrols}

Resveratrol (21) is a polyphenol compound derived from stilbenoid which is contained in a variety of plants including grapes and nuts. ${ }^{39}$ Several ester derivatives of resveratrol (21) have been synthesized through the esterification reaction through chemical and enzymatic reactions. Ester of resveratrol that has been reported in the synthesis process include 4'-acetate resveratrol (22), 4'-isobutyrate resveratrol (23), 4'-butyrate resveratrol (24), 4'-pivalate resveratrol (25), 4'-benzoate resveratrol (26), 3-acetate resveratrol (27), 3,4',5-triacetate resveratrol (28), 4'-octanoate resveratrol (29) 3,5-dioctanoate resveratrol (30) and 3,4',5-trioctanoate resveratrol.

Selective resveratrol esterification reaction at position 4' such as 4'-acetate resveratrol (22), 4'-isobutyrate resveratrol (23), 4'-butyrate resveratrol (24), 4'-pivalate resveratrol (25), and 4'-benzoate resveratrol 26 is carried out under thermodynamic conditions using acid anhydrides and $\mathrm{NaH}$ base catalysts. ${ }^{40}$ The 4 '-acetate resveratrol (22) was also synthesized through the reaction between acetic anhydride and various base catalysts and solvents. Each reaction condition includes acetic anhydride, $\mathrm{K}_{2} \mathrm{CO}_{3}$ base, and $\mathrm{EtOH}$ solvent at room temperature; acetic anhydride, base $\mathrm{InCl}_{3}$, and $\mathrm{MeCN}$ solvent at room temperature and acetic anhydride, $\mathrm{Et}_{3} \mathrm{~N}$ base, and DMSO at $65^{\circ} \mathrm{C}$. The reaction used $\mathrm{Et}_{3} \mathrm{~N}$ and DMSO solvents gave a maximum yield of 4 '-acetate resveratrol (22) of $47.00 \%{ }^{26}$

The mixture of 4-acetate resveratrol (22) and 3-acetate resveratrol (27) was synthesized by reaction between resveratrol and acetic anhydride with some base catalysts such as pyridine, $\mathrm{NaOH}, \mathrm{K}_{3} \mathrm{CO}_{3}$ and $\mathrm{NaH}$ and some lewis base catalysts such as $\mathrm{FeCl}_{3}, \mathrm{NiCl}_{2}, \mathrm{InCl}_{3}$, $\mathrm{ErCl}_{3}, \mathrm{TiCl}_{3} \cdot 4 \mathrm{H}_{2} \mathrm{O}$, and $\mathrm{TiO}_{2}$ and used several solvents such as acetic acid, THF, $\mathrm{MeCN}, \mathrm{CH}_{2} \mathrm{Cl}_{2}, \mathrm{EtOH}, \mathrm{H}_{2} \mathrm{O}$ and DMSO. The reaction used of $\mathrm{NaH}$ base, and THF solvents give 4'-acetate resveratrol (22) and 3-acetate resveratrol (27) products most at $47.00 \%$ and $9.40 \%{ }^{40} 3,4^{\prime}, 5$-triacetate resveratrol (28) was synthesized through the reaction between resveratrol and acetyl chloride, $\mathrm{Et}_{3} \mathrm{~N}$, and acetone for 16 hours at room temperature. This reaction produced ester of $78 \%$. 3,4',5-triacetate resveratrol (28) was also synthesized from the reaction of resveratrol with acetic anhydride, pyridine and acetic acid solvent and the reaction between resveratrol with acetyl chloride and pyridine and $\mathrm{CH}_{2} \mathrm{Cl}_{2}$ solvent at room temperature. ${ }^{41}$ 4'-octanoate resveratrol (29), 3,5-dioctanoate resveratrol (30) and 3,4',5-trioctanoate resveratrol (31) were mixed products from the reaction between octanoyl chloride as an acyl donor with $\mathrm{Et}_{3} \mathrm{~N}$ and ethyl acetate solvents at $25^{\circ} \mathrm{C}$ for 12 hours. ${ }^{6}$

Several researchers also reported the processes of resveratrol ester synthesis through enzymatic reactions. 4-acetate resveratrol (22) and 3,5,4'-triacetate resveratrol (28) were obtained through an enzymatic esterification reaction. 4-acetate resveratrol (22) was synthesized by added the enzyme Candida antartica to the resveratrol solution (dissolved in t-amyl alcohol solvent) containing vinyl acetate. 3,5,4'-triacetate resveratrol (28) was synthesized by added the enzyme Candida antartica into resveratrol solution (dissolved in $\mathrm{BuOH}$ solvent) containing acetic anhydride and pyridine. The mixture was incubated at $40^{\circ} \mathrm{C}$ at $400 \mathrm{rpm}$ (Figure 6) (Table 4). ${ }^{42}$<smiles>Oc1ccc(/C=C/c2cc(O)cc(O)c2)cc1</smiles><smiles>Cc1ccc(C=Cc2cc(C)cc([N+](=O)[O-])c2)cc1</smiles> 


\begin{tabular}{llll}
\hline Compounds & $\mathbf{R}_{\mathbf{1}}$ & $\mathbf{R}_{2}$ & $\mathbf{R}_{3}$ \\
\hline$(22)$ & $\mathrm{H}$ & $\mathrm{H}$ & $\mathrm{COCH}$ \\
$(23)$ & $\mathrm{H}$ & $\mathrm{H}$ & $\mathrm{COCH}\left(\mathrm{CH}_{3}\right)_{2}$ \\
$(24)$ & $\mathrm{H}$ & $\mathrm{H}$ & $\mathrm{COC}_{3} \mathrm{H}_{7}$ \\
$(25)$ & $\mathrm{H}$ & $\mathrm{H}$ & $\mathrm{COC}\left(\mathrm{CH}_{3}\right)_{3}$ \\
$(26)$ & $\mathrm{H}$ & $\mathrm{H}$ & $\mathrm{COPh}$ \\
$(27)$ & $\mathrm{H}$ & $\mathrm{COCH}_{3}$ & $\mathrm{H}$ \\
$(28)$ & $\mathrm{COCH}$ & $\mathrm{COCH}_{3}$ & $\mathrm{COCH}_{3}$ \\
$(29)$ & $\mathrm{H}$ & $\mathrm{H}$ & $\mathrm{COC}_{8} \mathrm{H}_{17}$ \\
$(30)$ & $\mathrm{H}$ & $\mathrm{COC}_{8} \mathrm{H}_{17}$ & $\mathrm{COC}_{8} \mathrm{H}_{17}$ \\
$(3 \mathrm{I})$ & $\mathrm{COC}_{8} \mathrm{H}_{17}$ & $\mathrm{COC}_{8} \mathrm{H}_{17}$ & $\mathrm{COC}_{8} \mathrm{H}_{17}$
\end{tabular}

Figure 6 Esterification reaction of resveratrol.

Table 4 Reagents, conditions and yield in esterification reactions of resveratrol

\begin{tabular}{|c|c|c|c|c|c|}
\hline Compounds & R Reagent & Catalyst/Enzyme & $\mathbf{T}\left({ }^{\circ} \mathrm{C}\right)$ & Yield (\%) & Reference \\
\hline \multirow[t]{3}{*}{$(22)$} & Acetic anhydride & $\mathrm{Et} 3 \mathrm{~N}$ & 65 & 47,00 & Lepart et al., ${ }^{26}$ \\
\hline & Acetic anhydride & $\mathrm{NaH}$ & 65 & 40,00 & Acerson \& Andrus, ${ }^{40}$ \\
\hline & Vinil asetat & Candida antartica & & 40,00 & Nicolosi et al., ${ }^{42}$ \\
\hline (23) & Isobutyric anhydride & $\mathrm{NaH}$ & 65 & 43,00 & Acerson \& Andrus, ${ }^{40}$ \\
\hline (24) & Anhidrida butirat & $\mathrm{NaH}$ & 65 & 46,00 & Acerson \& Andrus, ${ }^{40}$ \\
\hline$(25)$ & Anhidrida pivalat & $\mathrm{NaH}$ & 65 & 58,00 & Acerson \& Andrus, ${ }^{40}$ \\
\hline (26) & Benzoil klorida & $\mathrm{K} 2 \mathrm{CO} 3$ & 65 & 32,00 & Acerson \& Andrus, ${ }^{40}$ \\
\hline \multirow[t]{2}{*}{$(27)$} & Acetic anhydride & $\mathrm{NaH}$ & 65 & 9,40 & Acerson \& Andrus, ${ }^{40}$ \\
\hline & Acetic anhydride & Candida antartica & 40 & 30,00 & Nicolosi et al., ${ }^{42}$ \\
\hline (28) & Acetyl chloride & $\mathrm{Et} 3 \mathrm{~N}$ & $\mathrm{rt}$ & 78,00 & Jing, ${ }^{41}$ \\
\hline (29) & Octanoyl chloride & $\mathrm{Et} 3 \mathrm{~N}$ & 25 & $* N D$ & Hu et al., ${ }^{6}$ \\
\hline (30) & Octanoyl chloride & $\mathrm{Et} 3 \mathrm{~N}$ & 25 & $* N D$ & Hu et al., ${ }^{6}$ \\
\hline (3I) & Octanoyl chloride & $\mathrm{Et} 3 \mathrm{~N}$ & 25 & $* N D$ & Hu et al., 6 \\
\hline
\end{tabular}

*ND, no data

\section{Ester derivatives of terpenes}

Several kaurenoic esters namely methylkaur-16-en-19-oate (33), butylkaur-16-en-19-oate (34), Benzylkaur-16-en-19-oate (35), 4-chlorobenzylkaur-16-en-19-oat (36), 4-bromobenzilkaur-16-en19-oat (37), 4-florobenzilkaur-16-en-19-oat (38), 4-nitrobenzilkaur16-en-19-oat (39) have been synthesized from kaurenoic acid. These compounds were obtained through the esterification reaction of kaurenoic acid with suitable alkyl halides namely $\mathrm{CH}_{3} \mathrm{I}$ for (33), $\mathrm{C}_{4} \mathrm{H}_{9} \mathrm{Br}$ for (34), $\mathrm{PhCH}_{2} \mathrm{Br}$ for (35), 4- $\mathrm{ClPhCH}_{2} \mathrm{Br}$ for (36),
4- $\mathrm{BrPhCH}_{2} \mathrm{Br}$ for (37), 4- $\mathrm{FPhCH}_{2} \mathrm{Br}$ for (38), and 4- $\mathrm{NO}_{2} \mathrm{PhCH}_{2} \mathrm{Br}$ for (39), in $\mathrm{KOH}$-acetone at $25^{\circ} \mathrm{C}$ (Figure 7) (Figure 8) (Table 5). ${ }^{43}$

Derivative ester of betilinic acid (40), namely bentulinyl hexanoate (41) has been synthesized from the reaction between betulinic Acid with hexanoyl chloride and DMAP (4-dimethylamino pyridine) as catalyst in $\mathrm{CH}_{2} \mathrm{Cl}_{2}$. The reaction mixture was reacted at room temperature for $24-48$ hours. This process gave yield of $94 \%$ (Figure 9). ${ }^{44}$

Table 5 Yields of kaurenoic esters compound

\begin{tabular}{llllllll}
\hline Compounds & $(33)$ & $(34)$ & $(35)$ & $(36)$ & $(37)$ & $(38)$ & $(39)$ \\
\hline Yield (\%) & 89 & 71 & 91 & 48 & 74 & 37 & 21 \\
\hline
\end{tabular}




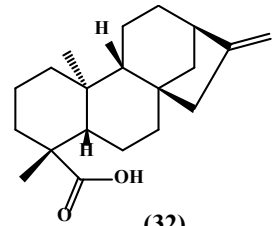

(32)

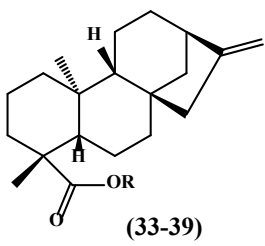

(33-39)
(34) $R=$ Buthyl

(35) $R=$ Benzyl

(36) $R=$ Benzyl Chloride

(37) $R=$ Benzyl Bromide

(38) $\mathrm{R}=$ Benzyl Fluoride

(39) $R=$ Nitro Benzyl
(33) $\mathrm{R}=$ Methyl

Figure 7 Structure of kaurenoic acid compound and kaurenoic acid I derivative esters.

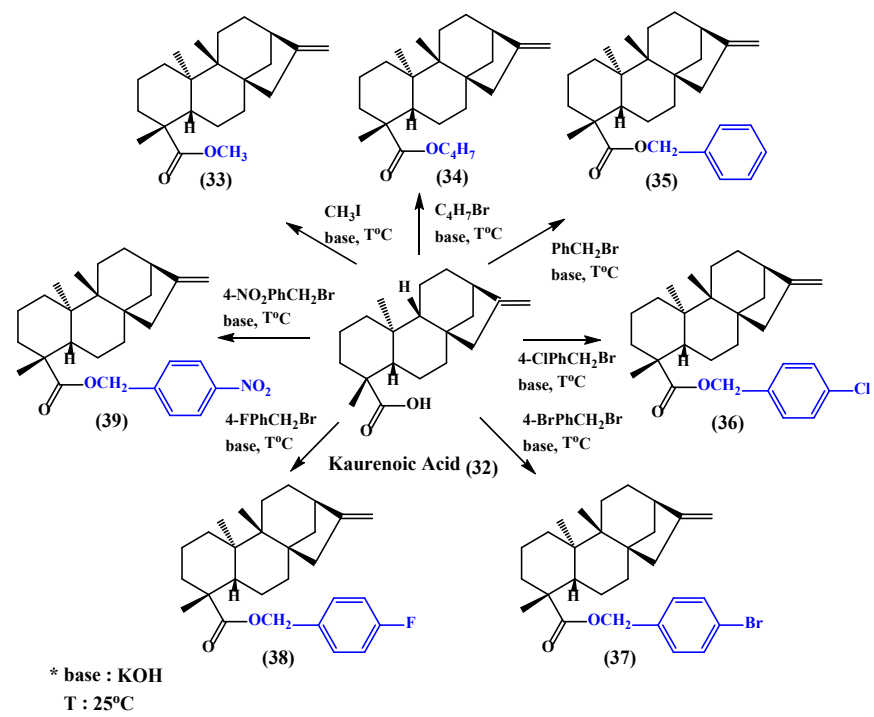

Figure 8 Esterification reaction of kaurenoic acid.
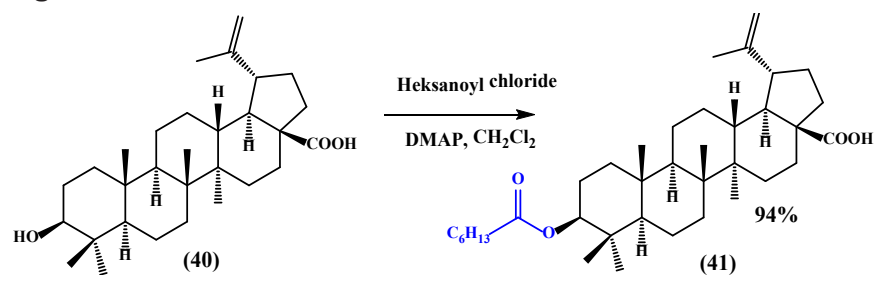

Figure 9 Esterification reaction of betulinic acid.

Terpenoid ester compounds have also been synthesized through an esterification reaction with an enzymatic catalyst. Geranyl acetate and geranil benzoate ester compounds have been synthesized from geraniol [3,7-dimethylocta-2,6-dien-1-ol (42)] namely 3,7-dimethylocta-2,6dien-1-yl acetate (43) and 3,7-dimethylocta-2,6-dien-1-yl benzoate (44). 3,7-dimethylocta-2,6-dien-1-yl acetate (43) was synthesized by the reaction between 3,7-dimethylocta-2,6-dien-1-ol (42) and vinyl acetate in toluene with the enzyme Pseudomonas cepacia lipase as a catalyst at $55^{\circ} \mathrm{C}$ for 3 hours. This reaction produced $99 \%$ of ester. ${ }^{20}$ Whereas 3,7-dimethylocta-2,6-dien-1-yl benzoate (44) was obtained by the esterification reaction of 3,7-dimethylocta-2,6-dien1-ol (42) with benzoic acid, diethylazodicarboniclicate (DED) and triphenylphosphite $\left(\mathrm{PPh}_{3}\right)$ in THF at $0{ }^{\circ} \mathrm{C}$. This process produced $95 \%$ ester product (Figure 10). ${ }^{45}$

Other terpene ester derivatives have also been synthesized. 2-(4-methylcyclohex-3-en-1-yl) propan-2-yl acetate (46) was synthesized from 2-(4-methylcyclohex-3-en-1-yl)propan-2-ol (45) and acetic anhydride in supercritical carbon dioxide $\left(\mathrm{SC}_{-} \mathrm{CO}_{2}\right)$ with enzymatic catalysis using $\mathrm{C}$. rugosa lipase. The reaction mixture of (45) compound and acetic anhydride is added to the reactor, followed by addition of $\mathrm{C}$. rugosa lipase. After that $\mathrm{CO}_{2}$ is pumped into the reactor and the esterification reaction is carried out at $10 \mathrm{MPa}$ and $50^{\circ} \mathrm{C}$ for 1.5 hours with at $250 \mathrm{rpm}$. This process produced $53 \%$ of ester. $^{46}$ 3,7-dimethylox-2-en-1-yl acetate (48) was synthesized from 3,7-dimethylox-2-en-1-ol (47) with vinyl acetate in n-hexane solvent. The reaction was catalyzed by Pseudomonas sp. The reaction mixture was incubated at $30^{\circ} \mathrm{C}$ at $200 \mathrm{rpm}$ for 24 hours. ${ }^{47}$ The geranil benzoate ester namely (1S)-2-isopropyl-5-methylcyclohexane-1-yl benzoate (50) was produced through the Mitsonabu esterification reaction of (1R)-2-isopropyl-5-methylcyclohexane-1-ol (51) with benzoic acid, diethylazodicarbonicate (DED) and triphenylphosphite $\left(\mathrm{PPh}_{3}\right)$ in THF at $0^{\circ} \mathrm{C}$. This process gave yield of $95 \%$ (Figure 11) (Figure 12). ${ }^{45}$

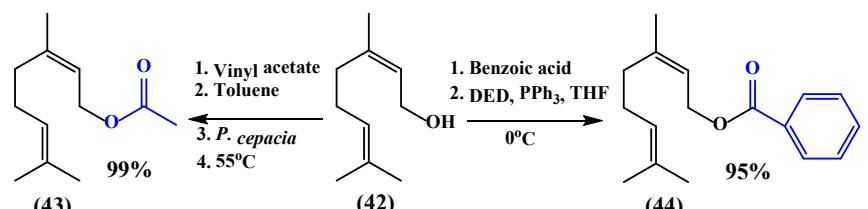

(43)

(42)

(44)

Figure I0 Reaksi esterifikasi of geraniol.
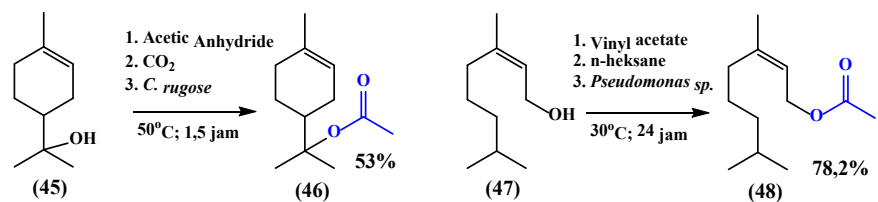

Figure I I Formation reaction of acetic terpenes.

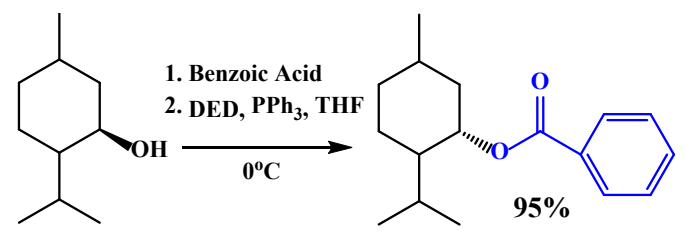

(49)

(50)

Figure 12 Formation reaction of benzoic terpenes.

The process of synthesis of ester compounds from citronellol was also reported. The citronellyl acetate (52) was synthesized by the reaction of citronellol (51) with vinyl acetate in $\mathrm{n}$-hexane solvent and catalyzed by Pseudomonas sp. The reaction mixture was incubated at $30^{\circ} \mathrm{C}$ at $200 \mathrm{rpm}$ for 24 hours. This process gave ester product of $80.2 \%{ }^{47}$ The citronellyl acetate (52) was also synthesized by the enzymatic reaction using the Carica papaya lipase as a catalyst to gave yield of $99 \%{ }^{48}$ The citronellyl acetate (52) was also obtained from the reaction mixture of dry n-hexane, citronellol (51), acetic acid and catalyzed by Candida antarctica lipase. The reaction mixture was incubated at $30^{\circ} \mathrm{C}$ and $200 \mathrm{rpm}$ to give an ester product of $98 \% .^{49}$ The citronellyl malonate (53) was synthesized using by the C. rugose enzyme as a catalyst. Malonic acid was reacted with citronellol (51) and inserted into a reactor that contains the lipase enzyme at $310 \mathrm{~K}$. This process produced yield of $98 \%$ (Figure 13). ${ }^{50}$

Ester derivative of menthol namely mentyl propionate (55), was synthesized through the enzymatic reaction using the lipase enzyme AY-30 from Candida cylindracea. Menthol (54) was dissolved in n-hexane and reacted with propionic anhydride. The mixture was incubated for 48 hours at $30^{\circ} \mathrm{C}$. Yield of ester product is $30 \%$ (Figure 14). ${ }^{51}$

The esterification of terpenes was also used ionic liquids as catalysts in reactions. Geraniol acetate (43), terpineol acetate (46) citronellol acetate (52), and mirceneol acetate (57) was synthesized using Sulfonic Functionalized Ionic Liquids (SFILs) as a catalyst. Terpenol acetate was obtained by reacted each terpenol using acetic anhydride with catalyst (SFILs). The sterification by SFILs catalysts gave high yield more than $90 \%$ (Figure 15)..$^{52}$ 


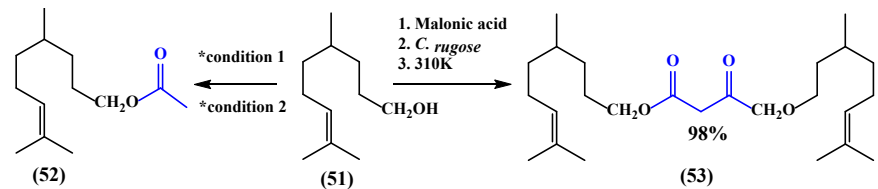

*condition 1 : vinyl acetate, Pseudomonas $s p$., $30^{\circ} \mathrm{C}$, yield $80,2 \%$

*condition 2 : acetic anhydride, C. antartica, $30^{\circ} \mathrm{C}$, yield $98 \%$

Figure 13 Formation reaction of citronellol esters.<smiles>CC1CCC(C(C)C)C(O)C1</smiles>

(54)

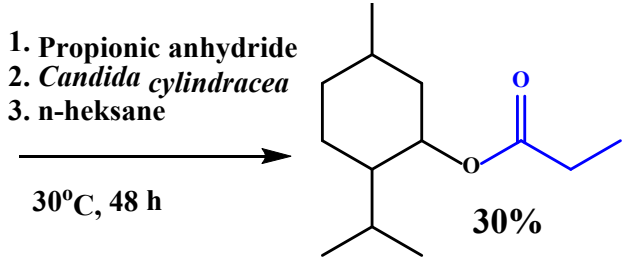

(55)
Figure 14 Esterification reaction of menthol.<smiles>CC(C)=CCCCCCCC(=O)OCC=C(C)C</smiles>

(42)

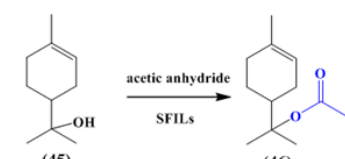

(46)

(45)<smiles>CCCCC(C)C(CCCC)CCCC(C)=O</smiles>

C

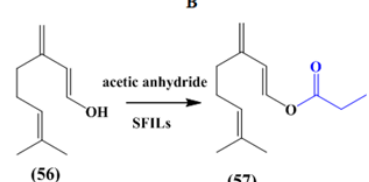

Figure I 5 Formation Reaction of Esters: A. geraniol acetate, B. terpineol acetate, $C$. citronellol acetate and D. mirceneol acetate.

Several esters of terpenoids alcohol with phenolic acid were synthesized including 1,3,3-trimethylbicyclo-[2.2.1]-heptan-2yl-3,4-dihydroxybenzoate (58), 1,3,3-trimethylbicyclo-[2.2.1]heptan-2-yl-3,4,5-trihydroxybenzoate (59), 1,3,3-trimethylbicyclo[2.2.1]-heptan-2-yl-3-(4-hydroxy-3-methoxyphenyl)acrylate (60), 1,3,3-trimethylbicyclo-[2.2.1]-heptan-2-yl-3-(3,4-dihydroxyphenyl) acrylate (61). All of these esters were synthesized by estrification reaction of monoterpenic fencol with various phenolic acids (protokatekuat acid for (58) compound, gallic acid for (59) compound, caffeic acid for (60) compound, and ferulic acids for (61) compound) and N,N-Dicyclohexylcarbodiimide (DCC) in THF for 24 hours at room temperature (Figure 16) (Figure 17). ${ }^{53}$

\section{Derivative esters of steroid}

Steroid derivative esters compound 5 $\alpha$-Androstan-17 $\beta$-(6methylheptan-2-yl)-30 $\beta$-yl benzoate (63) was synthesized from the steroid compound 5 $\alpha$-Androstan-17 $\beta$ - (6-methylheptan-2-il)-30 $\beta$ ol (62) through the esterification reaction of Mitsonabu by reacted steroids and benzoic acid with diethylazodicarbonicate (DED) and triphenylphosphite $\left(\mathrm{PPh}_{3}\right)$ in THF at $0^{\circ} \mathrm{C}$. This process gave yield of $65 \%{ }^{45} 5 \alpha$-Androstan-30 $\beta$, 17 $\beta$-diol-3-acetate (65), 5-Androsten-3 $\beta$, $17 \beta$-diol-3-acetate (67) and 5-Androsten-3 $\beta, 6 \beta$-diol-17-on-3- acetate (69) more obtained from the reaction of $5 \alpha$-Androstan-30 $\beta, 17 \beta$ diol (64) (for (65) compound), 5-Androsten-3 $\beta, 17 \beta$-diol (66), (for (67) compound), and 5-Androsten-3 $\beta, 6 \beta$-diol-17-on (68) (for (65)

compound) with vinyl acetate. Each reaction mixture was dissolved in a THF solvent and the reaction was catalyzed by C.a.B. lipase. The reaction mixture was shaken at $45^{\circ} \mathrm{C}$ for 40 hours. ${ }^{54}$

Cipoterone (70) derivative esters have been synthesized including cipoteronyl propionate (71) and cipoteronyl benzoate (72). Ciprotonil propionate (71) was synthesized through the esterification reaction between cipoteronil (70) with propionyl chloride and $\mathrm{N}$-Bromosuccinimide in $\mathrm{CH}_{2} \mathrm{Cl}_{2}$ for 12 hours. Cipoteronyl benzoate (72) was synthesized from the reaction of cipoteron (70) with benzoic acid using $\mathrm{H}_{2} \mathrm{SO}_{4}$ and acetonitrile for 20 hours (Figure 18) (Figure 19). ${ }^{55}$<smiles>[R3]c1c(Br)cc(C(=O)O)cc1Br</smiles>

Protocatekuic Acid : $\mathrm{R}_{1}=\mathrm{R}_{2}=\mathrm{OH} ; \mathrm{R}_{3}=\mathrm{H}$ Gallic Acid $\quad: \mathrm{R}_{1}=\mathrm{R}_{2}=\mathrm{R}_{3}=\mathrm{OH}$<smiles>[R3]c1ccc(/C=C/C(=O)O)cc1Br</smiles>

Cafeic Acid : $\mathrm{R}_{1}=\mathrm{R}_{2}=\mathrm{OH}$ Ferulic Acid : $\mathrm{R}_{1}=\mathrm{OMe} ; \mathrm{R}_{2}=\mathrm{OH}$<smiles>CC1(C)C2CCC1(C)C(O)C2O</smiles>

Fencol
Figure 16 Structure of terpenoids alcohol and phenolic acid.<smiles>[R]c1c(Br)cc(/C=C/C(=O)O)cc1Br</smiles><smiles>[R3]c1c(Br)cc(C=CC(=O)OC2C3CCC(C)(C3)C2(C)C)cc1Br</smiles>

\begin{tabular}{lllll} 
Compounds & $\mathbf{N}$ & $\mathbf{R}_{\mathbf{1}}$ & $\mathbf{R}_{\mathbf{2}}$ & $\mathbf{R}_{\mathbf{3}}$ \\
\hline 58 & 0 & $\mathrm{OH}$ & $\mathrm{OH}$ & $\mathrm{H}$
\end{tabular}

$59 \quad 0 \quad \mathrm{OH} \quad \mathrm{OH} \quad \mathrm{OH}$

$60 \quad \mathrm{I} \quad \mathrm{OH} \quad \mathrm{OH} \quad \mathrm{H}$

61 $\mathrm{O} \mathrm{OH} \quad \mathrm{OMe} \quad \mathrm{H}$

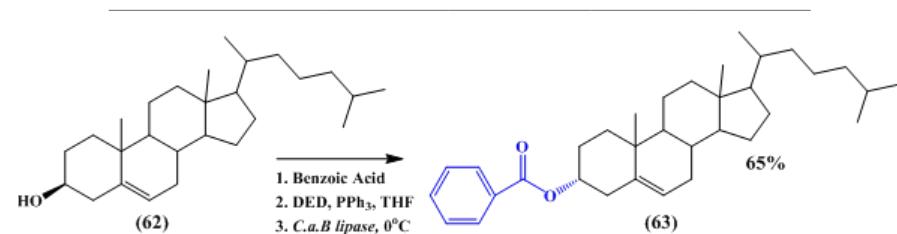

Figure 17 Esterification reaction of terpenes alcohol.<smiles>CC(=O)O[C@H]1CCC2(C)C(=CCC3C2CCC2(C)C(O)CCC32)C1</smiles>

(67)
(66)

Figure 18 Esterification reaction of steroids. 
<smiles>CC1CC2C3CCC(=O)C3(C)CCC2C2(C)CC[C@H](C)C=C12</smiles>

(68)<smiles></smiles>

(70)

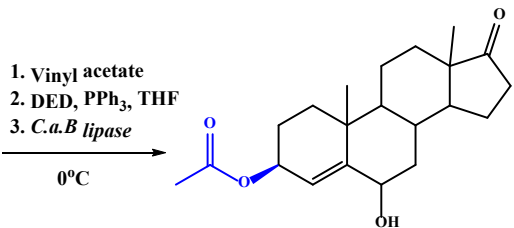

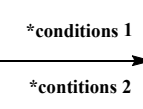

contitions 2
(69)

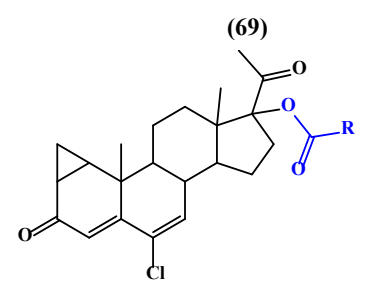

(71) $R$ : phenyl *condition 1 : propionyl chloride, $\mathrm{N}-\mathrm{Bromosuccinimide}, \mathrm{CH}_{2} \mathrm{Cl}_{2}, 12 \mathrm{~h}$, yield $91 \%$ (71) *condition 2 : benzoic acid, $\mathrm{H}_{2} \mathrm{SO}_{4}$, acetonitril, 20 h, yield $98 \%$ (72)

Figure 19 Esterification reaction of steroids.

\section{Bioactivity of esters derivatives from secondary metabolite compounds}

Esterification reaction in secondary metabolites is used to produce compounds that have different biological activities that are even better than the original compounds..$^{20,21}$ The compound eugenol acetate (7) has been reported have better anticancer activity compared to eugenol. Eugenol acetate compounds more actively inhibit the growth of KB cancer cells (oral squamous carcinoma cells) and DU-145 (androgeninsensitive prostate cancer cells) with $\mathrm{IC}_{50}$ values of eugenol acetate and eugenol in $\mathrm{KB}$ cells respectively $21.26 \times 10-6$ mol. $\mathrm{L}^{-1}$ and $28.48 \times 10^{-6}$ mol. $\mathrm{L}^{-1}$ and DU-145 cells respectively $21.5 \times 10^{-6} \mathrm{~mol} . \mathrm{L}^{-1}$ and $30.39 \times 10^{-6} \mathrm{~mol} . \mathrm{L}^{-1} \cdot{ }^{22}$ The addition of acetyl groups to eugenol was reported to increase the anti-inflammatory activity of eugenol because it can increase the selectivity of inhibiting prostaglandin formation in the COX-2 (cyclooxygenase 2) pathway. ${ }^{23,32}$ The eugenol acetate (7) was also reported to have potential as a compound that can be used in larvicidal formulations because the toxicity of eugenyl acetate against Aedes aegypti larvae is higher than eugenol with an $\mathrm{LC}_{50}$ value $0.102 \mathrm{mg} / \mathrm{mL} .{ }^{19}$ Therefore, eugenyl benzoate (9) has the potential as an antioxidant drug because it has been reported to have more antioxidant activity than the BHT used as a control. The antioxidant activity of eugenol benzoate is higher compared to eugenol with $\mathrm{IC}_{50}$ value for each compound that is $18.2 \mathrm{lg} / \mathrm{ml}$ and $20.20 \mathrm{lg} / \mathrm{ml} .^{24}$

Several ester derivatives of queccetin were reported for their biological activity. 3,3',4',7-tetraacetate quercetin was reported to have a different biological activity that is potentially antiviral to Human Respiratory Syncytial Virus (hRSV) which is a virus that causes pneumonia. This biological activity is not owned by quercetin. 3, 3', 4', 7-tetraacetate quercetin interacts with M2-1 protein from $\mathrm{hRSV}$ on the binding side of M2-1 RNA. Therefore, these compounds have the potential as inhibitors of hRSV virus replication. ${ }^{37}$ Compound of 3,3',5,7-tetraacetate quercetin was reported to have anti-inflammatory activity because it is able to inhibit the production of Nitrogen Oxide (NO) which acts as a proinflammatory mediator synthesized by inducible nitric oxide synthase (iNOS). ${ }^{38}$

3,3',4',7-tetraethylcarbamate quercetin (13) was reported to have higher permeability than quercetin so that they are able to more easily cross human epithelial cells (CaCo-2 cells). The transport rate of 3,3',4',7-tetraethylcarbamat quercetin (13) is significantly higher than the quercetin of $5.23 \times 10^{-6} \mathrm{~cm} / \mathrm{s}$, whereas the transport rate of quercetin is (10) $2.82 \times 10^{-6} \mathrm{~cm} / \mathrm{s} .{ }^{5} 3,3,4^{\prime}, 5,7$-pentaacetate quercetin (17) was reported to have higher bioavailability compared to quercetin (10) to human epithelial cells (MDCK-1 and MDCK-2). ${ }^{4}$ This compound was also reported to have anticancer activity against glioma cells whereas the quercetin did not have anticancer properties against glioma cells..$^{25}$ In addition, this compound was reported to have antiviral activity against Human Respiratory Syncytial Virus. ${ }^{37}$

The biological activity of resveratrol ester derivatives was also reported. 4'-acetate resveratrol (22) was reported to have antiaging activity. This compound significantly increased more than 3.3 times the gene expression of antiaging factors including extracellular matrix proteins (elastin and collagen III, IV), SIRT 1, MT1H (metalloproteinases), FBN1 (skin aging biomarkers fibrillin), LAMB1 (laminin), PCNA (proliferating cell nuclear antigen), and skin growth factors (HBEGF, IGF1, NGF, and TGF). The 4'-acetate resveratrol compound (22) also decreased the expression of inflammatory and aging skin molecular genes (COX-2, IL-1, IL-6, IL-8). Based on these data, 4'-acetate resveratrol (22) has the potential for the prevention and treatment of skin aging. ${ }^{26}$

The 4'-octanoate resveratrol (29), 3,5-dioctanoate resveratrol (30) and 3,4 ', 5-trioctanoate resveratrol (31) observed the stability of the gastrointestinal digestive system model and compared with resveratrol. The results reported that the bounded caprilate subtituents were relatively stable without hydrolysis in the mouth and gastric phase. However, in the intestine, the caprilate subtituents are not hydrolyzed and release resveratrol. This shows that caprilate esters from resveratrol can be absorbed by the intestinal lumen in the form of free resveratrol. ${ }^{6}$

Methylkaur-16-en-19-oat (33), Butylkaur-16-en-19-oat (34), Benzylkaur-16-en-19-oat (35), 4-Chlorobenzylkaur-16- en-19-oat (36), 4-Bromobenzilkaur-16-en-19-oat (37), 4-Fluorobenzylkaur-16en-19-oat (38), 4-Nitrobenzylkaur-16-en- 19-oat (39) were reported to have lower antifungal activity than the original compound namely kaurenoic acid. Bentulinil hexanoate compound (41) was reported to have antitumor activity against cells SF-295, HCT-116, PC-3 and HL60 but the activity of bentulinyl hexanoate (41) on each tumor cell is still lower compared to bentulinc Acid (40). Esterification of bentulinc Acid causes a decrease in antitumor (Table 6). ${ }^{44}$

Table 6 Bioactivity of esters derivatives from secondary metabolite compounds

\begin{tabular}{|c|c|c|c|}
\hline No. & Compounds & Bioactivity & Reference \\
\hline (7) & eugenyl acetate & Anticancer \& antiinflamatory & Carrasco et al.., ${ }^{22}$; Riswanto, ${ }^{23}$ \& Saraphanchotiwitthaya, et al., ${ }^{32}$ \\
\hline (9) & eugenyl benzoate & antioxidant & Horchani et al.., ${ }^{24}$ \\
\hline (II) & $3,3^{\prime}, 4^{\prime}, 7$-tetraacetate quercetin & antiviral & Guimaraes et al.,. ${ }^{37}$ \\
\hline$(12)$ & 3,3',5,7-tetraacetate quercetin & antiinflamasi & Ortega et al., ${ }^{38}$ \\
\hline (13) & 3,3',4',7-tetraethylcarbamate quercetin & high bioavailability & Hu et al., ${ }^{5}$ \\
\hline
\end{tabular}


Table Continued...

\begin{tabular}{|c|c|c|c|}
\hline No. & Compounds & Bioactivity & Reference \\
\hline$(22)$ & 4'-acetate resveratrol & antiaging & Lepart et al., ${ }^{26}$ \\
\hline (29) & 4'-octanoate resveratrol & hydrolyzed in the intestine & Nicolosi et al., ${ }^{42}$ \\
\hline (30) & 3,5-dioctanoate resveratrol & hydrolyzed in the intestine & Nicolosi et al., ${ }^{42}$ \\
\hline$(3 I)$ & 3,4',5-trioctanoate resveratrol & hydrolyzed in the intestine & \\
\hline (33) & Methylkaur-16-en-19-oate & antifungal & Boecka et al., ${ }^{43}$ \\
\hline (34) & Butylkaur-16-en-19-oate & antifungal & \\
\hline (35) & Benzylkaur-16-en-19-oate & antifungal & \\
\hline (36) & 4-chlorobenzylkaur-16-en-19-oate & antifungal & \\
\hline (37) & 4-bromobenzylkaur-16-en-19-oate & antifungal & \\
\hline (38) & 4-fluorobenzylkaur-16-en-19-oate & antifungal & \\
\hline (39) & 4-nitrobenzil kaur-16-en-19-oate & antifungal & \\
\hline$(4 I)$ & Bentulinyl hexanoate & antitumor & Vicktor et al., ${ }^{44}$ \\
\hline (58) & $\begin{array}{l}\text { I,3,3-trimethylbicyclo[2.2.I] heptan-2-yl- } \\
\text { 3,4-dihydroxybenzoate }\end{array}$ & $\begin{array}{l}\text { lipoxygenase enzyme } \\
\text { inhibitors }\end{array}$ & Sadegian et al., ${ }^{53}$ \\
\hline (59) & $\begin{array}{l}\text { I,3,3-trimethylbicyclo [2.2.I] heptan-2- } \\
\text { yl-3,4,5-trihydroxybenzoate }\end{array}$ & $\begin{array}{l}\text { lipoxygenase enzyme } \\
\text { inhibitors }\end{array}$ & \\
\hline$(60)$ & $\begin{array}{l}\text { I,3,3-trimethylbicyclo[2.2.I]heptan- } \\
\text { 2-yl-3-(4-hydroxy-3-methoxyphenyl) } \\
\text { acrylate }\end{array}$ & inhibitor enzim lipoksigenase & Sadegian et al., ${ }^{53}$ \\
\hline (38) & $\begin{array}{l}\text { I,3,3-trimethylbicyclo[2.2.I] heptan-2-yl- } \\
\text { 3-(3,4-dihydroxyphenyl)acrylate }\end{array}$ & $\begin{array}{l}\text { lipoxygenase enzyme } \\
\text { inhibitors }\end{array}$ & \\
\hline
\end{tabular}

\section{Conclusion}

Secondary metabolite compounds have a very diverse structure that is widely used as a source of new drug discovery because they have a variety of bioactivity. These compounds can be modified by esterification reaction with chemical and enzymatic reactions. Esters derivatives of secondary metabolite compounds can increase the diversity of structures, allow for increased biological activity and even new biological activity of these compounds. Based on this review, some of the ester compounds produced have not yet reported for their biological activity. In addition, there has not been much modification of the structure of other secondary metabolite compounds. Therefore, further research is needed to increase the diversity of structures and enable the discovery of potential new biological activities, so that the discovery of new drugs is developing.

\section{Acknowledgments}

None.

\section{Funding}

None.

\section{Conflicts of interest}

The authors declare there are no conflicts of interest.

\section{References}

1. Dewick PM. Medicinal natural product: a biosynthetis approach. 3rd Ed UK: John Willey \& Son; 2009.
2. Zhang L, demain L. Natural products: drug discovery and theraupetic medicine integrated approach. US: Humana Press; 2005.

3. Yao H, Liu J, Xu S, et al. The structural modification of natural products for novel drug discovery. Expert Opinion on Drug Discovery. 2016;12(2):121-140.

4. Biasutto L, Ester ME, Umberto UD, et al. Ester-based precursors to increase the bioavailability of quercetin. Journal of Mededicinal Chemistry. 2007;50:241-253.

5. $\mathrm{Hu} \mathrm{J}, \mathrm{Zou} \mathrm{X}, \mathrm{He}, \mathrm{Y}$, et al. Esterification of quercetin increases its transport across human caco-2 cells. Journal of Food Science. 2016;15(7):47224736.

6. Hu XP, Yin FW, Zhou DY, et al. Stability of resveratrol esters with caprylic acid during simulated in vitro gastrointestinal digestion, Food Chemistry. 2019;276:675-679.

7. Galan GC, Murcia AB, Lafuente FR, et al. Potential of different enzyme immobilization strategies to improve enzyme performance. Synthesis Catalyst. 2011;353:2885-2904.

8. Martins AB, Graebin NG, Lorenzon ASG, et al. Rapid and high yields of synthesis of butyl acetate catalyzed by Novozym 435: Reaction optimization by response surface methodology. Process Biochemistry. 2011;46:2311-2316.

9. Sangaletti-Gerhard N, Cea M, Risco V, et al. In situ biodiesel production from greasy sewage sludge using acid and enzymatic catalysts. Bioresource Technology. 2015;179:63-70.

10. Cipolatti EP, Valério A, Henriques RO, et al. Nanomaterials for biocatalyst immobilization-state of the art and future. Journal of Food Chemistr. 2016;6:104675-104692 
11. Compton DL, Laszlo JA, Berhow MA. Lipase-catalyzed synthesis of ferulate esters. Journal of Oil Chemistry. 2000;77(5):513-519.

12. Jaeger KE, Eggert T. Lipases for biotechnology. Biotechnology. 2002;1:390-397.

13. Guyot B, Bosquette B, Pina M, et al. Esterification of phenolic acids from green coffee with an immobilized lipase from Candida antarctica in solvent-free medium. Biotechnology Letters. 1997;19(6):529-532.

14. Sharma CK, Chauhan GS, Kanwar SS. Synthesis of medically important ethyl cinnamate ester by porcine pancreatic lipase immobilized on poly (AAc-co-HPMA-cl-EGDMA) hydrogel. Journal of Applied Polymer Science. 2011;121:2674-2679.

15. Zhang DH, Li YQ, Li C, et al. Kinetics of enzymatic synthesis of $\mathrm{L}$ ascorbyl acetate by Lipozyme TLIM and Novozym 435. Biotechnology Bioprocess. 2012;17:60-66.

16. Jakovetic SM, Lukovic ND, Boskovic-Vragolovic NM, et al. Comparative study of batch and fluidized bed bioreactions for lipase-catalyzed ethyl cinnamate synthesis. Industrial and Engineering Chemistry Research. 2013;52:16689-16697.

17. Vanin AB, Orlando T, Piazza SP, et al. Antimicrobial and antioxidant activities of clove essential oil and eugenyl acetate produced by enzymatic esterification. Application Biochemistry Biotechnology. 2014;8(8):327332 .

18. Wang Y, Zhang DH, Zhang JY, et al. High-yield synthesis of bioactive ethyl cinnamate by enzymatic esterification of cinnamic acid. Food Chemistry. 2016;190:629-633.

19. Machado JR, Pereira GN, Oliveira Z, et al. Synthesis of eugenyl acetate by immobilized lipase in a packed bed reactor and evaluation of its larvicidal activity. Arabian Journal of Chemistry. 2011;9:889-892.

20. Badgujar KC, Bhanage BM. Synthesis of geranyl acetate in non-aqueous media using immobilized Pseudomonas cepacia lipase on biodegradable polymer film: Kinetic modelling and chain length effect study. Process Biochem. 2014;49:1304-1313.

21. Chen B, Liu H, Guo Z, et al. Lipase-catalyzed esterification of ferulic acid with oleyl alcohol in ionic liquid/isooctane binary systems. Journal of Food Chemistry. 2011;59:1256-1263.

22. Carrasso H, Espinoza L, Cardile V, et al. Eugenol and its synthetic analogues inhibit cell growyh of human cancer cells, Journal of the Brazilian Chemical Society. 2011;19(3):543-548.

23. Riswanto FD.O. Synthesis of acetyl eugenol from eugenol and acetic acid anhydride with the sodium hydroxide catalyst. Skripsi, Universitas Sanata Dharma; 2011

24. Horchani H, Salem NB, Zarai Z, et al. Enzymatic synthesis of eugenol benzoate by immobilized Staphylococcus aureus lipase: Optimization using response surface methodology and determination of antioxidant activity. Bioresource Technology. 2010;101:2809-2817.

25. Dell'Albani P, Marco BD, Grasso S, et al. Quercetin derivatives as potent inducers of selective cytotoxicity in glioma cells. European Journal of Pharmaceutical Sciences. 2017;101:56-65.

26. Lephart ED, Acerson MJ, Andrus MB. Synthesis and skin gene analysis of 4-acetoxy-resveratrol (4AR), therapeutic ential for dermal applications. Bioorganic \& Medicinal Chemistry Letters. 2016;26(14):3258-3262.

27. Wang Y, Zhang DH, Chen N, et al. Synthesis of benzyl cinnamate by enzymatic esterification of cinnamic acid. Bioresource Technology. 2015;198:256-261.

28. Wang Y, Zhang DH, Chen N, et al. Synthesis of benzyl cinnamate by enzymatic esterification of cinnamic acid. Bioresource Technology. 2015;198:256-261
29. Gao Z, Chu J, Jiang T, et al. Lipase immobilization on functionalized mesoporous $\mathrm{TiO}_{2}$ : Specific adsorption, hyperactivation and application in cinnamyl acetate synthesis. Process Biochemistry. 2018;64:152-159.

30. Manopo YA. Isolation of oil of clove oil and separation of eugenol and acetyl eugenol. An instructive experiment for beginning chemistry under graduates. 2010;53(4):263.

31. Santosa PD, Zabot GL, Meireles MAA, et al. Synthesis of eugenyl acetate by enzymatic reactions in supercritical carbon dioxide. Biochemical Engineering Journal. 2016;114:1-9.

32. Saraphanchotiwitthaya A, Khorana N, Sripalakit, P. Comparative anti-inflammatory activity of eugenol and eugenyl acetate on the murine immune response in vitro. Journal of Science Technology. 2019;41(3):641-648.

33. Chaibakhsh N, Basri M, Anuar SHM, et al. Optimization of enzymatic synthesis of eugenol ester using statistical approaches, Biocatalysis and Agricultural Biotechnology. 2012;1:226-231.

34. Manan FMA, Rahmana IND, Marzuki NHC, et al. Statistical modelling of eugenol benzoate synthesis using Rhizomucormiehei lipase reinforced nano bioconjugates. Process Biochemistry. 2016;51(2):249-262.

35. Manan FMA, Attan N, Zakaria Z, et al. Enzymatic esterification of eugenol and benzoic acid by a novel chitosanchitin nanowhiskers supported Rhizomucor miehei lipase: Process optimization and kinetic assessments. Enzyme and Microbial Technology. 2018;108:42-52.

36. Mattarei A, Biasutto L, Rastrelli F, et al. Regioselective $O$-derivatization of quercetin via ester intermediates. an improved synthesis of rhamnetin and development of a new mitochondriotropic derivative. Molecules. 2010;15:4722-4736.

37. Guimaraes GC, Piva HRM, Araujo GC, et al. Binding investigation between M2-1 protein from Hrsv and acetylated quercetin derivatives: ${ }^{1} \mathrm{H}$ NMR, fluorescence spectroscopy, and molecular docking. International Journal of Biological Macromolecules, 2018;111:33-38.

38. Ortega MG, Saragusti AC, Cabrera JL, et al. Quercetin tetraacetyl derivative inhibits LPS-induced nitric oxide synthase (iNOS) expression in J774A.1 cell. Archives of Biochemistry and Biophysics. 2010;498:105110 .

39. Granados SV. Pleiotropic effects of resveratrol. Drug News Perspect. 2003;16(5):299-307.

40. Acerson MJ, Andrus MB. Selective esterification of the polyphenol resveratrol at the 4'-position. Tetrahedron Letters. 2014;55(3):757-760.

41. Jing SM. Synthesis of resveratrol esters and aliphatic acids, Thesis. Department of Chemistry East Tennessee State University; 2011.

42. Nicolosi G, Spatafora, C, Tringali C. Chemo-enzymatic preparation of resveratrol derivatives. Journal of Molecular Catalysis B Enzymatic. 2002;16:223-229.

43. Boecka P, Marcus M, Souza BS, et al. A simple synthesis of kaurenoic esters and other derivatives and evaluation of their antifungal activity. Journal of Brazil Chemistry Soc. 2005;16(6B):1360-1366.

44. Victor MM, David JM, Sakukuma MCK, et al. Terpene Esters from Natural Products: Synthesis and Evaluation of Cytotoxic Activity. Annals of the Brazilian Academy of Sciences. 2017;89(3):1369-1379.

45. Lakoud SG, Djerourou A. Esterification and etherification of steroid and terpene under Mitsunobu conditions. Arabian Journal of Chemistry. 2011;9:889-892.

46. Liaw ET, Liu KJ. Synthesis of terpinyl acetate by lipase-catalyzed esterification in supercritical carbon dioxide. Bioresource Technology. 2010;101:3320-3324. 
47. Akoh CC, Yee LN. Lipase-catalyzed transesterification of primary terpene alcohols with vinyl esters in organic media. Journal of Molecular Catalysis Enzymatic. 1998;4:149-153.

48. You P, Su E, Yang X, et al. Carica papaya lipase-catalyzed synthesis of terpene esters. Journal of Molecular Catalysis B: Enzymatic. 2011;71:152-158.

49. Claon PA, Akoh CC. Effect of reaction parameters on SP435 lipasecatalyzed synthesis of citronellyl acetate in organic solvent. Enzyme and Microbial Technology. 1994;16(10):835-838.

50. Serri NA, Kamaruddin AH, Len KYT. A continuous esterification of malonic acid with citronellol using packed bed reactor: Investigation of parameter and kinetics study. Food and Bioproducts Processing. 2010;8(8):327-332.

51. Wu WH, Akoh CC, Phillips RS. Lipase-catalyzed stereoselective esterification of menthol in organicsolvents using acid anhydrides as acylating agents. Enzyme and Microbial Technology. 1996;18:538-539.
52. Tao DJ, Dong Y, Cao ZJ, et al. Tuning the acidity of sulfonic functionalized ionic liquids for highly efficient and selective synthesis of terpene esters. Journal of Industrial and Engineering Chemistry. 2016;41:122-129.

53. Sadeghian H, Seyedi MS, Jafari Z. Design and synthesis of new esters of terpenoid alcohols as 15-lipoxygenase inhibitors. Iranian Journal of Basic Medical Sciences. 2018;21:7.

54. Bertinotti A, Carrea G, Ottotina G, et al. Regioseiective Esterification of Polyhydroxylated Steroids by Candida antarctica Lipase B, tetrahedron. 1994;54(46):13165-13172.

55. Rezaei Z, Khabnadideh S, Zarshenas M, et al. Esterification of tertiary alcohols in steroids under different conditions. Journal of Molecular Catalysis A: Chemical. 2007;276:57-61. 